\title{
Pierwsze napisane po polsku teksty poświęcone matematyce a współczesne piśmiennictwo dydaktyczne. Strategie komunikacyjne w dyskursie edukacyjnym
}

We współczesnych badaniach poświęconych komunikacji coraz częściej podkreśla się potrzebę uwzględnienia nowej kategorii opisu, jaką jest dyskurs. Można jednak spojrzeć nań także jako na przedmiot opisu, formę praktyki komunikacyjnej, strumień tekstów zjednoczonych wspólnotą tematyczną, stosunkiem do opisywanej rzeczywistości, aksjologią, przyjęciem względnie stałego scenariusza komunikacyjnego owocującego stabilnością struktur narracji, stosownym doborem środków stylistycznych i językowych. Przyjęcie nowej optyki oglądu mechanizmów komunikacji, zaistnienie w refleksji naukowej kategorii i przedmiotu opisu wcześniej (pod koniec XX wieku) nieznanych powszechnie rodzi pytanie dotyczące skutków poznawczych, metodologicznych zrodzonych przez taki zabieg. Można by rzec, że w badaniach językoznawczych dyskurs stał się na przełomie stuleci obligatoryjną kategorią opisu (Gajda 1999, s. 9-18; Witosz 2003, s. 89-103; Wojtak 2011, s. 69-78), poszerzającą pole analizy, ujawniającą nowy wymiar funkcjonowania tekstu ujmowanego wcześniej jako bazowa (terminalna) jednostka analizy lingwistycznej (Heinemann 2009, s. 361-379). Nowe spojrzenie nań pozwoliło ująć go w kategoriach jednostki komunikacji uwikłanej w relacje z innymi jednostkami dyskursu, traktowanego jako zbiory tekstów powiązanych różnorakimi więzami. O relewancji tekstu, traktowanego jako podstawowa jednostka komunikacji, przesądza zatem jeszcze jedna cecha (zob. cechy konstytutywne tekstu - Warnke 2009, s. 343-360), mianowicie dyskursywność, co oznacza, że dyskurs jest kategorią pozwalającą pełniej uchwycić wymiar tematyczny, ontologiczny, aksjologiczny, strukturalny, stylistyczno-językowy tekstu. Jeśli zatem dyskurs we współczesnych badaniach jest ujmowany 
jako zdarzenie komunikacyjne, strumień tekstów powiązanych siecią różnorakich zależności, to w sposób oczywisty rodzi się możliwość ukazania tekstu jako konkretnego aktu komunikacji, osadzonego w jednostkowej sytuacji, uwikłanego jednocześnie w płaszczyznę transtekstualną, jaką jest dyskurs. Nowa perspektywa oglądu pozwala zobaczyć, jak owo splecenie się rzutuje na procedury tekstotwórcze, jak dyskurs konstytuuje znaczenie tekstu.

Istotne $\mathrm{w}$ refleksji poświęconej relacji tekst-dyskurs jest spojrzenie na nią przez pryzmat jeszcze jednej kategorii, jaką jest gatunek. Problematyka ta doczekała się w lingwistyce niezwykle bogatej literatury. Przyjęto, czerpiąc z genologii (Witosz 2005b, s. 21-26, 475-494), precyzyjną wykładnię gatunku, czego dowodem na gruncie polskim są m.in. prace Bożeny Witosz i Marii Wojtak. Potraktowanie gatunku jako wzorca (Wojtak 2004, s. 14-25) czy modelu (Witosz 2002, s. 268-285, 2003, s. 89-103), będącego instrumentem rozpoznawania relewantnych wykładników tekstów (podpowiadających scenariusz odbioru), prowadzi jednocześnie w stronę konstatacji, iż jest on konstruktem (pojęciem wziętym z planu ideacji), traktowanym jako kategoria typologiczna (opisu) umożliwiająca spojrzenie na konkretny tekst (gatunek w takim ujęciu nie jest bowiem kategorią empiryczną) przez pryzmat wyznaczników strukturalnych, stylistycznych, pragmatycznych, treściowych (ujawniających stosunek utrwalonego obrazu świata do rzeczywistości pozajęzykowej, zawierających wykładnię aksjologiczną) oraz (w planie najszerszym) kulturowych. Przyjęty schemat poznawczy jest konsekwencją maksymalnie szerokiego oglądu mechanizmów komunikacji.

Dyskurs edukacyjny (Nocoń 2009, s. 20-21) niewątpliwie można w świetle powyższych uwag potraktować jako zbiór norm, konwencji czy wzorów zachowań komunikacyjnych, projektujących sferę dydaktyczną, która ma charakter instrukcyjny (implikujący zachowania w sferze kontaktów społecznych wyznaczonych przez modus: ekspert przekazujący wiedzę-jej adept) i regulacyjny (odpowiadający za propagowanie i utrwalanie norm istotnych w życiu społecznym). Teksty wytworzone w owej sferze ujawniają względnie stały stosunek do opisywanej rzeczywistości, zbieżną postawę poznawczą (świat jako struktura poznawalna, niesprzeczna, tożsama), czytelną aksjologię, wyprofilowane są przez ten sam typ relacji pragmatycznych. Teksty poddane względnie stałemu scenariuszowi komunikacyjnemu (z jednoznacznie zarysowanymi celami, czytelnie wyznaczonymi rolami komunikacyjnymi) cechuje $\mathrm{w}$ związku $\mathrm{z}$ tym podobny zbiór właściwości strukturalnych, językowych, stylistycznych.

Niewątpliwie gatunkiem obecnym w sferze komunikacji edukacyjnej jest podręcznik utożsamiany z tekstem (zob. książka szkolna — Nocoń 1997, s. 11), którego można użyć w procesie kształcenia w celu realizacji zadań dydaktycznych czy wychowawczych (Nocoń 1997, s. 11-15). Podręcznik ujmowany jest zatem jako gatunek, który prymarnie reguluje i projektuje zachowania uczestników komunikacji poddanej trybowi edukacyjnego oglądu rzeczywistości. Podręcznik jest gatunkiem, którego wymiar edukacyjny w planie formalnym należy 
utożsamiać z płaszczyzną informacji oraz planem sterowania jej przyswajaniem. Jednocześnie w podręczniku istotną rolę odgrywają operatory zawiadujące procesem reprodukowania wiedzy (zob. komponent orientacyjny w strukturze podręcznika — Nocoń 1997, s. 19-20).

We współczesnym dyskursie edukacyjnym (Nocoń 2009) podręcznik (mimo istnienia odrębnych pól referencji) ma względnie stabilną strukturę, cechuje go homogeniczna szata stylistyczna, językowa, wyznaczony jest przez przewidywalne komponenty planu pragmatycznego. Jednocześnie perspektywa diachroniczna pozwala ukazać go jako strukturę dynamiczną, sterowaną przez splot różnorakich czynników natury poznawczej i komunikacyjnej. Podręcznik bowiem ewoluuje pod wpływem trendów kultury, jego historia wyznaczona jest przez etapy poszukiwania optymalnych środków kompozycyjnych, stylistycznych czy językowych ułatwiających transfer informacji, zarządzanie procesem jej przyswajania. Należy w nim widzieć formę, która zmieniała się i zmienia nadal wraz z rozwojem poznania naukowego, kształtowaniem się szerokiej sfery odbiorców — adeptów wiedzy oczekujących komunikatów, które przybliżając osiągnięcia nauki, pozwalają rozwiązywać konkretne problemy, zrodzone np. w sferze praktyki gospodarczej, społecznej czy kulturowej. Podręcznik zatem, projektując scenariusz dialogu wyznaczony przez linię napięć komunikacyjnych: ekspert-uczeń, dostosowuje doń określony zestaw środków wyrazu.

Pierwsze napisane po polsku teksty, których celem było edukowanie, instruowanie, udzielanie porad, zrodziły się w XVI wieku (Więsław 1997, s. 268-288; Biniewicz 2002, s. 201-305, 2010, s. 39-50). Fakt ich zaistnienia był motywowany właśnie potrzebą poinformowania praktyków — kupców, rzemieślników, mierniczych, adeptów wiedzy — o osiągnięciach nauki pozwalających stosować rozwiązania teoretyczne w praktyce, instruować, w jaki sposób można efektywnie zarządzać projektami gospodarczymi, wykonywać zadania, które zrodziła dynamicznie rozwijająca się w owym czasie gospodarka polska. Nie dziwi zatem fakt, iż zawierały one kurs podstaw arytmetyki, geometrii czy miernictwa. Pierwsze teksty, które można nazwać w związku z tym podręcznikami, tak naprawdę, gdyby zastosować współczesne kryteria oceny, nie we wszystkich aspektach za takowe byłyby dziś uznane. Pamiętać jednak należy, że nie ma gatunku pojmowanego w kategoriach czegoś niezmiennego, niepodlegającego ewolucji, wszak teksty są ogniwami komunikacji konkretnych wspólnot cechujących się określonymi nawykami komunikacyjnymi, sterowanych przez ustalenia kultury. Innymi słowy, nieuprawomocnione jest stwierdzenie, że istnieje jakiś stały wzorzec podręcznika. Możemy zatem mówić, gdy przedmiotem analizy czynimy szesnastowieczne teksty, wpisane w nurt komunikacji edukacyjnej, iż podręcznik (pojmowany jako model tekstu) musi być traktowany jako struktura poznawcza (jednocześnie produkt komunikacji) o następującej architekturze: gatunek jest konstruktem (czyli zbiorem cech przypisywanym typowi tekstów) o mocy kodyfikacji, wpływającym na kształt narracji, projektującym tryb odbioru. Jednocześnie — skoro przynależy 
on do sfery realizacji — należy w nim ujrzeć nie tylko wiązkę cech, jednocześnie warto bowiem nań spojrzeć jako na konkretną realizację (konkretny egzemplarz), poddaną presji impulsów kulturowych, sytuacyjnych, sterowanych przez uwarunkowania pragmatyczne, profilującą pod ich wpływem właściwości strukturalne, stylistyczne planu wyrażania, ujawniającą konkretną postawę poznawczą gospodarza wywodu, kreślącą w określony sposób status ontologiczny rzeczywistości poddanej opisowi.

Niewątpliwie analiza diachroniczna poświęcona podręcznikowi ujawniająca dynamikę kształtowania się gatunku (Gajda 2001, s. 263) musi uwzględniać fakt, iż pojawił się on w polskim (i europejskim) piśmiennictwie na szerszą skalę dopiero na przełomie XVI i XVII wieku w sytuacji kształtowania się nowych scenariuszy komunikacji (Ostaszewska 1994, s. 91-92, 2004, s. 217-229), aczkolwiek stosunkowo liczne teksty o podobnym nacechowaniu pragmatycznym, rysujące identyczne cele, podporządkowujące im formę (kompozycję, styl, język), proponowały zbieżny format, poddany mniej lub bardziej uświadamianej normatywizacji. Można zatem ostrożnie przyjąć, że pierwsze napisane po polsku traktaty mające wiele cech właściwych podręcznikowi, powstałe w XVI wieku, mają charakter heterogeniczny, są bowiem po trosze wykładem, monografią, mają cechy poradnika (Biniewicz 2007, s. 61-67). Pierwsze polskie traktaty, które traktowano jako podręczniki, były strukturami synkretycznymi, integrującymi w polu narracji zarządzanej przez jednego gospodarza różne niekiedy scenariusze zachowań komunikacyjnych. Należy je traktować jako formy polifunkcyjne, obciążone wieloma zadaniami w komunikacji naukowej czy edukacyjnej.

Przegląd pierwszych napisanych po polsku książek naukowych osadzonych w dyskursie edukacyjnym jednoznacznie wskazuje, że cechuje je zestaw komponentów charakterystycznych dla płaszczyzny informacji oraz przyswajania wiedzy obecnej we współczesnym podręczniku, zob.: definicje, opisywanie zasad, wyjaśnienia, uzasadnienia, sięganie po przykłady, klasyfikowanie, stawianie pytań i odpowiadanie na nie, posługiwanie się poleceniami dydaktycznymi (Biniewicz 2007, s. 63-67, 2011, s. 111-122, 2013a, s. 7-24). Jednocześnie komponent werbalny jest $\mathrm{w}$ badanych książkach wzmacniany za pomocą struktur pozawerbalnych (właściwych także współczesnym podręcznikom, zob. Nocoń 2009, s. 214-246), czego dowodem są (Biniewicz 2002, s. 211-216): mapa graficzna tekstu, traktowana jako komponent sterujący strukturą wykładu, aktywizujący odbiorcę, kooperowanie pola graficznego z płaszczyzną leksykalną (tworzenie się dwóch uzupełniających się strumieni narracji).

Wyrazem takiej tendencji jest np. Algorytm (1538) Tomasza Kłosa, pierwszy napisany po polsku traktat poświęcony podstawom arytmetyki. Kłos, pisząc swój Algorytm, niewątpliwie posiłkował się istniejącymi już w Europie, Polsce arytmetykami cyfrowymi i liniowymi. Stanisław Dobrzycki (1957, s. 3-18) w szkicu poświęconym Algorytmowi Bernarda Wojewódki podaje, iż w szesnastowiecznym Krakowie ukazało się kilkadziesiąt wydań arytmetyk cyfrowych i liniowych, przy 
czym do 1553 roku jedynym polskim podręcznikiem był traktat Tomasza Kłosa. Porównanie dzieł, które funkcjonowały w owej dobie wśród kupców, rzemieślników, praktyków pragnących poznać podstawy arytmetyki, pozwala stwierdzić daleko idące podobieństwa, jeśli chodzi o kompozycję wykładu, zastosowane środki stylistyczne.

Kłos w Algorytmie dawał polskiemu praktykowi (kupcowi, rzemieślnikowi) wgląd w zasady arytmetyki ułatwiające prowadzenie działalności gospodarczej, w owym czasie w Krakowie funkcjonowało bowiem kilkadziesiąt różnych jednostek miar, a ich przeliczanie było istotnym utrudnieniem w praktyce gospodarczej (Biniewicz 2010, s. 39-50). Traktat Kłosa nie był projektem wyjątkowym w szesnastowiecznej Europie, albowiem już na przełomie XV i XVI stulecia w różnych krajach ukazały się stosunkowo liczne podręczniki arytmetyki, algorytmy (zob. Ulrich Wagner Das Bamberger Rechenbuch - 1483, Luca Pacioli Divina proportione -1509, Adam Ries Rechenbuch auff Linien und Ziphren - 1518, Robert Recorde The Ground of Arts - 1543 czy Caspar Thierfelder Arithmetica oder Rechenbuch auff den Linien und Ziffern - 1587) adresowane do praktyków gospodarki, zawierające reguły arytmetyczne, dzięki którym można było stosunkowo szybko przeprowadzać różnorodne operacje obliczeniowe (zob. Newman 1956, s. 21-217; Smith 1925, s. 9-15, 190-191; Cajori 1993, s. 123).

Cóż zatem decyduje o tym, że traktaty powstałe w XVI wieku można uznać za pierwsze napisane po polsku podręczniki? Przede wszystkim są one produktem czytelnego schematu komunikacyjnego rysującego wyraziście linię napięć komunikacyjnych, przesądzających o pozycji gospodarza wywodu i miejscu, roli odbiorcy. Gospodarzami narracji pierwszych polskich traktatów realizujących zadania edukacyjne są eksperci, którzy o swoich kwalifikacjach mówią wprost lub pośrednio za pomocą struktur metatekstowych, stosownych form czasownika (zob. tryb rozkazujący w 2 os. 1. pojedynczej jako znak dyrektywności wywodu) czy świadomie dobranych wyrazów modalnych (zob. wypowiedzi T. Kłosa, S. Grzepskiego, Wojewódki - autorów szesnastowiecznych traktatów uznanych za podręczniki arytmetyki, geometrii, miernictwa: Więsław 1997, s. 264-277, 269-278; Biniewicz 2013b, s. 169-180). Warto zauważyć, że identyczną strategię komunikacji wpisaną w taki sam edukacyjny scenariusz można odnaleźć we współczesnych podręcznikach arytmetyki, matematyki. Zestawienie wypowiedzi autorów - gospodarzy wywodu, którzy zwracając się do odbiorcy, sięgają po 2 os. 1. pojedynczej, stosują czasowniki modalne, wprowadzają komentarz metatekstowy do wykładu czy nasycają go odesłaniami do innych tekstów w celu podkreślenia swej dominacji merytorycznej oraz komunikacyjnej, jest w tej materii pouczającą lekturą, zob.:

Nie musisz być matematykiem, żeby czerpać radość z uczenia się matematyki. Przy systematycznym uczeniu się matematyki napotkasz, oczywiście, zwykłe, nudne ćwiczenia, przypominające ćwiczenia z gramatyki, ale też intrygujące zadania czy nieoczekiwane zastosowania (Zakrzewski et al. 2002, s. 11). 
Przyglądając się tym rysunkom, można sformułować przypuszczenie, że [...] (Zakrzewski et al. 2002, s. 16).

Chociaż wnioski te są tylko przybliżone, w zasadzie dość dobrze stosują się do obcowania z tekstem pisanym, choć wówczas trzeba na ogół przyjąć, że język jest trochę bogatszy (Zakrzewski et al. 2002, s. 108).

W miejscach oznaczonych tym symbolem proponujemy rozwiązania tematycznych zestawów zadań [...]. Zadania w rozdziałach, tak jak w poprzednich klasach, są ułożone od bardzo łatwych po coraz trudniejsze. [...] Jeżeli rozwiążesz wszystkie zadania utrwalające, to znaczy, że rozumiesz i umiesz zastosować wiadomości zawarte w tym rozdziale [...] (Lewicka, Kowalczyk 2014, wstęp).

O kształcie podręcznika jako gatunku mowy przesądza zatem fakt zawiązania paktu komunikacyjnego, mającego wymiar poznawczy, pragmatyczny, aksjologiczny. Innymi słowy, kontrakt poznawczo-komunikacyjny łączący uczestników komunikacji ujętej w trybie edukacyjnym generuje określoną postawę poznawczą u autora (obraz świata utrwalony w przekazie, sfera wartości), wyzwala scenariusz komunikacyjny, który profiluje procedury zaznajamiania odbiorcy (adepta wiedzy) z dokonaniami nauki, wymusza szczególny typ kontaktów polegający na tym, że kompetentny komunikacyjnie ekspert mający dostęp do archiwum wiedzy steruje odbiorcą.

W konkretnych realizacjach schemat ów może podlegać modyfikacjom, może być aktualizowany za pomocą różnych wykładników, co jednak nie zmienia podstawowej relacji (Grochowski 2004, s. 23): o morfologii tekstu (zob. architektonika podręcznika - Nocoń 2009, s. 61-98) przesądzają czynniki pragmatyczne (relacja nadawczo-odbiorcza, intencja komunikacji).

Warto zatem przyjrzeć się scenariuszom wykładu treści naukowych w trybie edukacyjnym, polegającym na transmisji wiedzy od eksperta do nowicjusza w określonym planie kognitywnym (Nocoń 2009, s. 20), stosowanym przez autorów pierwszych napisanych po polsku traktatów matematycznych czy geometrycznych, transferowaniu ich do adresata, którym jest adept wiedzy, praktyk oczekujący rozwiązania konkretnych problemów za pomocą narzędzi dostarczonych przez naukę.

Dobrym przykładem w tej materii są szesnastowieczne traktaty: Algorytm Kłosa oraz Geometria Grzepskiego (Biniewicz 2013a, s. 7-24, 2013b, s. 169-180). Obaj autorzy, mając na uwadze cel edukacyjny, wiedząc, kim jest adresat ich wykładu, zaproponowali taki scenariusz komunikacji, który umożliwiłby odbiorcy w konkretnych sytuacjach (powtarzających się lub nietypowych, nowych) sięganie po istniejące schematy, wytworzone w dyskursie edukacyjnym. Jednocześnie gruntowne udokumentowanie metodologii naukowej, jako sprawnego instrumentu sprawczego, pozwoliło na twórcze modyfikacje, mutacje — zmianę istniejących 
schematów, generowanie nowych. Przyjęty scenariusz komunikacji pozwolił na precyzyjne zarysowanie schematu aktywności intelektualnej odbiorcy, który płynnie mógł przejść od czynności nieodwracalnych i konkretnych, bo dotyczących obiektów realnych, do działań mentalnych, przenoszących czynności konkretne w sferę wyobrażeniową, co prowadzi do aktywności logicznej, generalizowania, sięgania po abstrakcyjne operacje matematyczne - dzięki nim możliwe jest stwarzanie sytuacji problemowych, tworzenie abstrakcyjnych modeli rzeczywistości fizycznej, realnie doświadczanej.

Istotne dla obu autorów było kształtowanie podstawowych pojęć w taki sposób, aby podlegały one naturalnej matematyzacji, co najszybciej następowało w sytuacji rozwiązywania zadań niemających bezpośredniego związku z matematyką za pomocą instrumentów wytworzonych przez teorię matematyczną. Schemat komunikacji zaproponowany przez autorów wspomnianych traktatów można zatem ująć następująco: sytuacja w świecie realnie doświadczanym rodzi potrzebę jej rozwiązania, co jest możliwe dzięki procedurze jego matematyzacji, nauka stwarza bowiem abstrakcyjne modele świata fizycznego; rezultat działań analitycznych zapisany w postaci zdań zrozumiałych dla odbiorcy wraca do niego jako interpretacja problemu. Jednocześnie model matematyczny (jako konstrukt ujawniający podobieństwa i różnice, właściwości obiektów matematycznych) pozwala na swoiste rozwinięcie, szukanie innych sposobów rozwiązania tego samego zadania.

Dobrym przykładem ilustrującym powyższy scenariusz komunikacyjny jest fragment Geometrii poświęcony procedurom mierzenia obiektów fizycznych, np. wież, studni, placów czy pól (Biniewicz 2013b, s. 169-180). Grzepski wychodzi w swej pracy z założenia, że wytwarzanie sytuacji problemowej musi być poprzedzone wprowadzeniem koniecznych wiadomości, czyli definicji, twierdzeń czy dowodów, jako niezbędnego materiału teoretycznego pozwalającego zmierzyć się z konkretnymi zadaniami. Dlatego też pierwsza część Geometrii jest treściwym przywołaniem ustaleń zarysowanych w Elementach Euklidesa. Pojęcia teoretyczne są w dalszej części wykładu funkcjonalnym instrumentem matematyzacji rzeczywistości realnie doświadczanej. Ich wprowadzenie do wywodu jest eksplicytnym sygnałem orientacji poznawczej, przyjętego punktu widzenia. Procedura związana z mierzeniem placów, pólek, czyli obiektów niejednokrotnie nieregularnych, ujęta w planie refleksji wywiedzionej z geometrii Euklidesowej, sprawia, że stają się one bytami geometrycznymi, czyli idealnymi, bo pozbawionymi cech fizycznych. Grzepski, sięgając po leksykę naukową, ukazywał siłę narracji naukowej, która pozwala dostrzec w świecie natury czy kultury regularność, symetrię, proporcje. Abstrakcyjne myślenie odkrywające geometryczne zależności w świecie natury, język pozwalający precyzyjnie je ujawnić są czynnikami pozwalającymi porzucić potoczną perspektywę oglądu świata natury, wytworów kultury, zastąpić ją modelem matematycznym. Nowy język analizy i opisu zapożyczony z Elementów jest w wy- 
kładzie Grzepskiego narzędziem logicznego myślenia pozwalającego odpowiedzieć na pytania: co to jest?, jak można rozwiazać konkretny problem za pomoca abstrakcyjnie ujętych zależności? i jak działa matematyczny model świata fizycznego?

Rzecz znamienna, że wydany ponad trzysta lat później podręcznik Matematyka przyjemna i pożyteczna (Zakrzewski et al. 2002) przeznaczony dla uczniów I klasy szkoły średniej podejmuje ten sam wątek, sięga po identyczne uzasadnienia i - co ważne - wykorzystuje te same strategie komunikacyjne, tzn. zastępuje potoczny punkt widzenia naukowym, czego wyrazem jest zastosowanie terminologii do opisu czy analizy problemów doświadczanych potocznie.

Dobrą ilustracją strategii narracji zastosowanej przez autorów podręcznika jest rozdział poświęcony geometrii, w którym mowa jest o proporcjonalności obiektów geometrycznych. Autorzy, chcąc uzmysłowić uczniowi istotę problemu, posługują się prostym przykładem kartki formatu A4, którą można dzielić wzdłuż symetralnej dłuższego boku po to, by otrzymać identyczne kartki, proporcjonalnie zmniejszone, zob.:

Rozcinając kartkę A4 wzdłuż symetralnej dłuższego boku otrzymujemy dwie mniejsze kartki. [...] Zatem połówki kartki formatu A4 mają tę samą proporcję boków co cała kartka. Te połówki znów możemy podzielić na dwie równe części i tak dalej. Po ułożeniu wszystkich części w lewym górnym roku kartki, widzimy, że odpowiednie wierzchołki leżą na linii prostej. Jaki wniosek można wyciągnąć z faktu, że wierzchołki leżą na linii prostej? Jest to proporcjonalność [...]. Własność ta jest bardzo często wykorzystywana w praktyce. Wykonując jakiekolwiek operacje na połówce lub ćwiartce kartki formatu A4, uzyskujemy takie same proporcje figur, jakie uzyskalibyśmy, wykonując te same czynności na całej kartce (plik nr 32 na płycie CD dołączonej do podręcznika matematyki: Zakrzewski et al. 2002).

Wyjaśnienie w prosty sposób, poprzez odwołanie do sytuacji potocznej, czym jest proporcjonalność, pozwala zmierzyć się z konkretnymi zadaniami. Oto autorzy podręcznika formułują następujący problem: jak można zmierzyć wysokość drzewa, jeśli znamy długość jego cienia oraz wysokość osoby stojącej nieopodal i długość jej cienia:

Człowiek mający $1 \mathrm{~m} 80 \mathrm{~cm}$ wzrostu rzuca cień długości $1 \mathrm{~m} 20 \mathrm{~cm}$, a drzewo rzuca w tym czasie cień $6 \mathrm{~m}$. Oblicz wysokość drzewa (Zakrzewski et al. 2002, s. 209).

Rozwiązanie problemu jest podane za pomocą precyzyjnego języka matematyki, w którym człowiek, drzewo czy cień stają się proporcjonalnymi bokami podobnych trójkątów. Wskazanie na cechy podobieństwa trójkątów pozwala ułożyć równanie, dzięki któremu ustalenie wysokości żądanego obiektu nie jest już zadaniem skomplikowanym. Zwraca uwagę fakt, że w opisie zadania nie ma 
już słów wziętych z języka ogólnego (człowiek, drzewo, cień), ich miejsce zajęły terminy trójkąt, bok trójkąta, proporcja:

Ponieważ promienie słońca biegną równolegle, więc trójkąty OAB oraz ODE są podobne. W obu trójkątach stosunek odpowiadających sobie boków jest więc taki sam. Zachodzi zatem $\mathrm{DE} / \mathrm{OD}=\mathrm{AB} / \mathrm{OA}$, czyli $\mathrm{x} / 6=1,80 / 1,20$. Stąd $\mathrm{x}=1,80 / 1,20 \cdot 6=9$. Tak więc drzewo ma 9 metrów wysokości (Zakrzewski et al. 2002, s. 209).

W Geometrii Grzepskiego można odnaleźć tak samo zaprojektowany wykład (Biniewicz 2013b, s. 169-180), podporządkowany identycznej strategii narracji, dotyczący procedury mierzenia wysokości wieży czy głębokości studni (zob. prawo Talesa). Szesnastowieczny traktat odkrywa (tak jak i współczesny podręcznik) przed czytelnikiem możliwość opisania rzeczywistości doświadczanej na co dzień, pełnej jednostkowych, niepoddanych standaryzacji realnych obiektów (np. wież, pól, studni, obiektów topograficznych), w kategoriach modelu ujawniającego proporcje i podobieństwo obiektów idealnych, bo abstrakcyjnych, czyli ujętych jako zbiór punktów w określonej przestrzeni. Model geometryczny nie jest zatem w ujęciu Grzepskiego tylko uproszczeniem rzeczywistości. Należy w nim widzieć analityczny opis obiektów istniejących w świecie realnie doświadczanym (o czym także dobitnie mówią autorzy współczesnego podręcznika matematyki: Zakrzewski et al. 2002, s. 183). Rzecz jasna o wartości zaproponowanego modelu przesądza - według Grzepskiego (podążającego tropem ówczesnych matematyków) - test wierzytelności, który ujawniając prawidłowości rządzące światem fizycznym, uświadamia potocznemu odbiorcy zgodność modelu teoretycznego ze zdroworozsądkowym opisem świata, pozwala zastosować język teorii do opisu i rozwiązania konkretnych zagadnień zaistniałych w świecie kultury.

Analiza pierwszych napisanych po polsku traktatów matematycznych, o których Witold Więsław (1997, s. 268), historyk matematyki, mówi wprost, iż były podręcznikami matematyki, geometrii, pozwala jednoznacznie stwierdzić, że konstytutywną wartość w procesie ich wytworzenia ma pakt komunikacyjno-poznawczy kreślący scenariusz edukacyjny, ustalający rolę gospodarza i adresata w strukturze wykładu, przesądzający o jego morfologii, środkach językowych i pozajęzykowych pozwalających funkcjonalnie zarządzać wytworzonym obrazem świata. Współczesne podręczniki matematyki będące owocem działań komunikacyjnych poddanych silnej normatywizacji różnią się niewątpliwie, jeśli mamy na uwadze kompozycję wykładu, zastosowane środki językowe, stylistyczne, od swoich szesnastowiecznych poprzedników, bo są owocem szeroko zakrojonych badań dotyczących procedur edukacyjnych, metod przekazywania wiedzy, a także sposobów optymalnego ich ujęcia za pomocą funkcjonalnie zaprojektowanych tekstów (Kojs 1970; Krygowska 1980; Giermakowski 1996; Legutko 2009). 
Niemniej jednak, jeśli patrzymy na podręcznik pojmowany jako gatunek, to Algorytm Kłosa oraz Geometria Grzepskiego muszą być traktowane jako teksty wpisane w rytm szesnastowiecznej kultury umysłowej, produkt wyrosły z dialogu pomiędzy tekstami, punkt zaistniały dzięki strumieniowi narracji (Heinemann 2009, s. 364) projektującej edukacyjny tryb kodowania rzeczywistości, poddawania jej waloryzacji podporządkowanej czytelnej ramie pragmatycznej, poszukiwania środków przekazu pozwalających optymalnie realizować założone cele.

\section{Bibliografia}

Biniewicz J. (2002), Kształtowanie się polskiego języka nauk matematyczno-przyrodniczych, Opole. Biniewicz J. (2007), Podręcznik naukowy jako gatunek mowy, [w:] Gatunki mowy i ich ewolucja, t. III. Gatunek a odmiany funkcjonalne, red. D. Ostaszewska, Katowice, s. 61-68.

Biniewicz J. (2010), „Algorytm” Tomasza Kłosa, czyli o pieniądzu i arytmetyce kupieckiej stów kilka, [w:] Monety, banknoty i inne środki wymiany, red. P. Kowalski, Wrocław, s. 39-50.

Biniewicz J. (2011), Rodzenie się polskiego dyskursu naukowego. Pragmatyka, struktura i język traktatu Olbrychta Strumieńskiego „O sprawie, sypaniu i rybieniu stawów”, [w:] Gatunki mowy $i$ ich ewolucja, t. IV. Gatunek a komunikacja społeczna, red. D. Ostaszewska, Katowice, s. $111-122$.

Biniewicz J. (2013a), Początki polskiego dyskursu naukowego (szesnastowieczne piśmiennictwo naukowe), [w:] Zielonogórskie seminaria językoznawcze 2011, red. M. Hawrysz, M. Uździcka, Zielona Góra, s. 7-24.

Biniewicz J. (2013b), O mierzeniu obiektów w traktacie Stanisława Grzepskiego słów kilka, [w:] Cum reverentia, gratia, amicitia... Ksiega jubileuszowa dedykowana Profesorowi Bogdanowi Walczakowi, red. J. Migdał, A. Piotrowska-Wojaczyk, Poznań, s. 169-180.

Cajori F. (1993), A History of Mathematical Notations, New York.

Dobrzycki S. (1957), Algorytm Bernarda Wojewódki (1553), „Kwartalnik Historii Nauki i Techniki” II, nr 1, s. 3-28.

Gajda S. (1999), Wspótczesny polski dyskurs naukowy, [w:] Dyskurs naukowy - tradycja, zmiana, red. S. Gajda, Opole, s. 9-18.

Gajda S. (2001), Gatunkowe wzorce wypowiedzi, [w:] Wspótczesny język polski, red. J. Bartmiński, Lublin, s. 256-268.

Giermakowski M. (1996), Jaki wybrać podręcznik szkolny, „Wiadomości. Opinie. Myśli”, nr 5.

Grochowski G. (2004), Czy istnieje tekst poza gatunkiem?, [w:] Gatunki mowy i ich ewolucja, t. II. Tekst a gatunek, red. D. Ostaszewska, Katowice, s. 20-28.

Heinemann W. (2009), Lingwistyka tekstu kontra lingwistyka dyskursu?, [w:] Lingwistyka tekstu w Niemczech. Pojęcia, problemy, perspektywy, red. D. Chemperek, A. Kalbarczyk, D. Trześniowski, Wrocław, s. 361-374.

Kojs W. (1970), Uwarunkowania dydaktycznych funkcji podręcznika WSiP, Warszawa.

Krygowska Z. (1980), Zarys dydaktyki matematyki, Warszawa.

Legutko M. (2009), O matematycznym modelowaniu różnych sytuacji przez uczniów gimnazjum i liceum. Współczesne problemy nauczania matematyki, Bielsko-Biała.

Lewicka H., Kowalczyk M. (2014), Matematyka wokót nas, Warszawa.

Newman J.R. (1956), The World of Mathematics, t. 1, New York.

Nocoń J. (1997), Polecenia i pytania w podręcznikach do nauki o języku, Opole.

Nocoń J. (2009), Podręcznik szkolny w dyskursie dydaktycznym — tradycja i zmiana, Opole.

Ostaszewska D. (1994), Z zagadnień ewolucji stylu naukowego: XVI-wieczne poczatki kształtowa- 
nia się wyznaczników przebiegu procesu myślowego, „Prace Językoznawcze” 22, s. 85-94.

Ostaszewska D. (2004), Przemiany sposobu istnienia gatunku — zarys problematyki (na materiale publicystki parlamentarnej), [w:] Gatunki mowy i ich ewolucja, t. II. Tekst a gatunek, red. D. Ostaszewska, Katowice, s. 217-229.

Smith D.E. (1925), History of Mathematics, t. 2, Boston.

Warnke I. (2009), Żegnaj tekście - witaj dyskursie?, [w:] Lingwistyka tekstu w Niemczech. Pojęcia, problemy, perspektywy, red. D. Chemperek, A. Kalbarczyk, D. Trześniowski, Wrocław, s. $343-360$.

Więsław W. (1997), Matematyka i jej historia, Opole.

Witosz B. (2002), Gatunek - sporny (?) problem najnowszej refleksji tekstologicznej, [w]: Sporne i bezsporne problemy wspótczesnej wiedzy o literaturze, red. W. Bolecki, R. Nycz, Warszawa 2002, s. 268-285.

Witosz B. (2003), Schematy, wzorce tekstowe, gatunki mowy... (O kategoryzacji, kategoriach wypowiedzi językowych i ich modelowaniu), „Przestrzenie Teorii” 2, Poznań, s. 89-103.

Witosz B. (2005a), Genologiczna przestrzeń tekstu. (O „Jadac do Babadag” Andrzeja Stasiuka), „Ruch Literacki” nr 4-5, s. 475-494.

Witosz B. (2005b), Genologia lingwistyczna. Zarys problematyki, Katowice.

Wojtak M. (2004), Gatunki prasowe, Lublin.

Wojtak M. (2011), O relacjach dyskursu, stylu, gatunku i tekstu, „Tekst i Dyskurs” 4, s. 69-78.

Zakrzewski M., Żak T., Jakubas E., Nodzyński P., Szuty J., Zakrzewska D. (2002), Matematyka przyjemna i pożyteczna. Podręcznik. Klasa 1, Warszawa.

\section{The first texts ever written in Polish devoted to mathematics and contemporary educational textbooks. Communication strategies in educational discourse}

\section{Summary}

In the first part of the article, the author considers the relationships between the essential concepts in the contemporary discourse in linguistics: discourse, text and types of speech. In the second part his considerations are focused on the structure and language of Grzepski’s Geometry and Kłos's Algorithmus as compared to contemporary Polish textbooks. The analysis of the sixteenth-century treatises on mathematics leads to the conclusion that the contract between the author of the treaty and his recipients plays the fundamental role in the process of creation of the Polish textbooks. The above-mentioned relation determines the morphology of the text, the image of the world presented in the narrative as well as linguistic and non-linguistic means of expression. The author concludes that the genre of Polish textbooks on mathematics as such was born in the sixteenth century.

Keywords: discourse, text and types of speech, educational textbook 